\title{
Study on Relationship between Student Satisfaction and Multi-media Classroom Environment
}

\author{
Min HUA \\ ${ }^{1}$ School of Foreign Languages, Wuhan Textile University, Wuhan, 430073, China \\ email: Rebecca_huamin@126.com
}

Key words: Multimedia classroom environment, Satisfaction; Learning style; Teaching style

\begin{abstract}
Multi-media classroom's characteristics fulfill the requirements for learning in a modern society .The researches on the student satisfaction with the multimedia classroom itself are few. Based on the previous research, the researcher of this thesis developed a comprehensive multi-media classroom satisfaction questionnaire. The purpose of this study is to investigate into student satisfaction with multimedia classroom environment.
\end{abstract}

\section{Introduction}

Given the massive utilization of the multi-media in higher education, student satisfaction within the context of the environment is clearly a factor of most importance in ensuring the validity of the education environment .Multi-media classroom's characteristics fulfill the requirements for learning in a modern society. [1]Previous studies have not studied the relationship between perceived student satisfaction and learning styles in a multimedia classroom environment. [2]Perceived learner satisfaction is defined as the degree of the learner satisfaction with learning environment as a whole. So this research synthesizes literature from learners' learning styles and multimedia classroom environment to investigate a model of learner satisfaction with multimedia classroom environment. [3] The model proposes the student satisfaction with the multimedia classroom environment is affected by the concrete environment in multimedia classroom as well as the preferred learning style of the students.

\section{Methodology}

Research questions

a. How are the students satisfied with the multimedia classroom environment?

b. What is the relationship between personal characteristics (learning styles, motivation, and English level) and their satisfaction with multi-media classroom?

Subjects

The subject was 220 non-English major undergraduates from Wuhan Textile university o (WTU), a comprehensive university in Wuhan, Central China. Among them, 200 students completed their questionnaire validly, the response rate resulting in 90.9\%. The sample consisted of 133males (66.5\%)and 67 female ( s33.5\%) .

Instrument

The first part is the Multimedia Classroom Environment Satisfaction Comprehensive Questionnaire; it was designed on the basis of related research in the multimedia classroom teaching. The second part is Kolb's Learning Style Inventory. The third part is the motivational intensity. Qualitative ways such as open-ended questions are necessary for the research to employ to get to know first -hand information about the subjects' real thoughts and their suggestions for improvement. [4]

Data Analysis

The procedure data analysis is as below. Firstly, we will obtain the student satisfaction with multimedia classroom through the spss13 transformation to solve the first research question. Secondly, with the perceived satisfaction as dependent variable (item24), one-way ANOVA was 
conducted to examine whether there are statistically significant differences in the four variables among the subjects by four learning styles. Thirdly Stepwise Multiply Regression were used to determine the nature and closeness (strongest to weakest associations ) of the relationships among the predictors (learner attribute and instructional variables ) and the criterion variables (perceived student satisfaction ) and among the 18 items within part1of the questionnaire and student satisfaction .For the stepwise regression ,entry values were set at $p=.05$. Lastly, content analysis of students' responses to the open-ended questions was performed to identify common experience with the multimedia classroom, students like and dislikes, and their suggestion for future improvements. Therefore, this study mainly conducted descriptive, Independent samples T-test, one-way ANOVA, Correlation and Stepwise multiple regression statistics.

\section{Results and Discussion}

\section{The student satisfaction with the multimedia classroom environment}

The students are more satisfied with courseware content than with courseware external manifestation and teaching style. [5]Most courseware displaying in the multimedia classroom is designed and produced by many experience experts and issued by prestigious publishing house. It is the achievement of many experts hard work. And some of the courseware is produced by teacher himself or herself.

Table 3.1Descriptive Statistics

\begin{tabular}{|l|l:l:l|}
\hline & N & Mean & Std. Deviation \\
\hline Courseware Demonstration & 200 & 9.4700 & 2.56162 \\
Courseware Content & 200 & 13.2050 & 2.72951 \\
Teaching Style & 200 & 33.8600 & 8.94542 \\
an 24 & 200 & 3.3550 & 3.64767 \\
Valid N & 200 & & \\
\hline
\end{tabular}

From the SPSS data, of all the 18 items in the first part of the whole questionnaire, the students are most satisfied with are item5, item1; the students are least satisfied with are item 2and item3.The MEANs of each item are: item5 is 4.0950; item 1 is 3.4900 . Item2 is 2.8050 and item3 is2.3450. That means the students are most satisfied with the size of the words on the screen, and second satisfied with the courseware manifesting with text, image, and sound at the same time. The students are least satisfied with multimedia operating and screen interval. Through our teaching experience and interview with the students we got to the truth that multimedia don't work well and screen interval is short that the students have not enough time to digest the contents .So these aspects the students are least satisfied with we should improve in the future.

The relationship between student characteristics and their satisfaction with multimedia classroom environment

Relation between learning style and student satisfaction with multimedia classroom

We can easily find out that $49 \%$ of the students is belonged to the third learning style: abstract logical .We figure that most of the male subjects and this very few top students admitted into Wuhan Textile University (WTU) after the college entrance examination accounting for the reason. And proportion of students learning style are concrete experience is $23.5 \%$, reflective observation is $14.5 \%$, abstract logical is $49 \%$ active experiment is $13 \%$. 
Table 3.2 Statistics

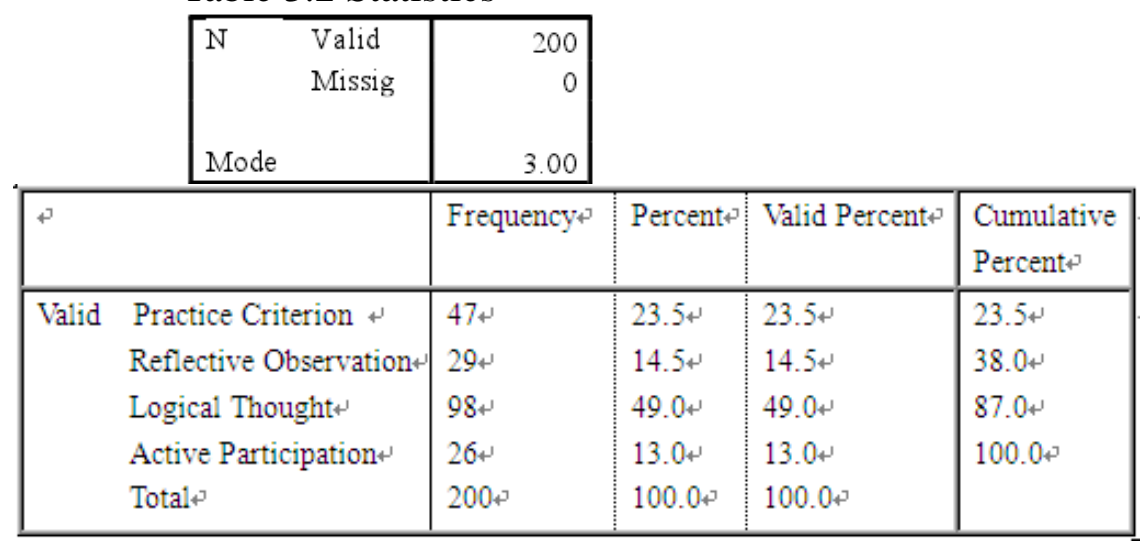

In order to examine the relationship between learning style and students' perceived satisfaction with multimedia classroom (pa24), one-way ANOVA analysis was conducted. Pa24 is the overall satisfaction.

Table 3.3 Descriptives an24

\begin{tabular}{|c|c|c|c|c|c|c|c|c|}
\hline \multirow[t]{2}{*}{ 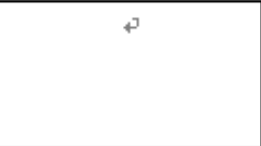 } & \multirow[t]{2}{*}{$\mathrm{No}$} & \multirow[t]{2}{*}{ Meant } & \multirow[t]{2}{*}{$\begin{array}{c}\text { Std. } \\
\text { Deviation }\end{array}$} & \multirow[t]{2}{*}{$\begin{array}{c}\text { Std. } \\
\text { Error }\end{array}$} & \multicolumn{2}{|c|}{$\begin{array}{c}95 \% \text { Confidence Interval for } \\
\text { Mean }\end{array}$} & \multirow[t]{2}{*}{ Minimum } & \multirow[t]{2}{*}{ maximum } \\
\hline & & & & & Lower Bound.r & Upper Bound.r & & \\
\hline Practice Criterion & 474 & 3.1915 & .68010 & .099204 & 2.9918 & 3.3912 & 2.00 & 5.00 \\
\hline Reflective Observation & $29+4$ & $3.5862+$ & 2.29156 & .42553 & 2.7145 & 4.4579 & 2.00 & 15.00 \\
\hline Logical Thought & $98+$ & $3.5306+$ & 5.00969 & .50606 & 2.5262 & 4.5350 & 1.00 & 52.00 \\
\hline Active Particip ation & $26+$ & $2.7308+$ & 1.07917 & .21164 & 2.2949 & 3.1667 & 1.00 & 5.00 \\
\hline Total & $200 *$ & 3.35504 & 3.64767 & .25793 & 2.8464 & 3.8636 & 1.00 & 52.00 \\
\hline
\end{tabular}

Table 3.3 is the descriptive of the four learning styles of which $\mathrm{N}$, Mean, Std. Deviation ,95\%confidence interval for Mean ,Minimum and Maximum are presented .And the Std. Deviation of each group is close to each other .That means the conditions for one-way ANOVA is accepted.

Table 3.4 Test of Homogeneity of Variances

\begin{tabular}{|r|r|r|r|}
\hline $\begin{array}{l}\text { Levene } \\
\text { Statistic }\end{array}$ & $\mathrm{df1}$ & $\mathrm{df2}$ & \multicolumn{1}{c|}{ Sig. } \\
\hline .480 & 3 & 196 & .696 \\
\hline
\end{tabular}

In table 3.4 the sig. in the test of homogeneity is .696 which is much higher than 0.05 . That means the results of the following one-way ANOVA analysis is effective.

Table 3.5 AVON

\begin{tabular}{|r|r|r|r|}
\hline $\begin{array}{l}\text { Levene } \\
\text { Statistic }\end{array}$ & $\mathrm{df1}$ & $\mathrm{df2}$ & \multicolumn{1}{c|}{ Sig. } \\
\hline .480 & 3 & 196 & .696 \\
\hline
\end{tabular}

In table 3.5 the $\mathrm{F}$ is .396 and the sig. is .756 which doesn't reach the significant level .000 . So there is no significant difference among the four learning styles between the learning style and the perceived satisfaction with multimedia classroom environment. 
Table 3.6 Dependent Variable: an24 Scheffe

\begin{tabular}{|c|c|c|c|c|c|c|}
\hline \multirow[t]{2}{*}{ (I) Leaming style } & \multirow[t]{2}{*}{ (J)Leaming Style } & \multirow{2}{*}{$\begin{array}{c}\text { Mean } \\
\text { Differences }\end{array}$} & \multirow[t]{2}{*}{ Std. Error } & \multirow[t]{2}{*}{ Sig. } & \multicolumn{2}{|c|}{$95 \%$ Confidence Interval for Mean } \\
\hline & & & & & Lower Bound.1. & Upper Bound.1 \\
\hline Practice Criterion & $\begin{array}{l}\text { Reflective Observation } \\
\text { Logical Thought } \\
\text { Active Participation }\end{array}$ & $\begin{array}{l}-.39472 \\
-.33912 \\
.46072\end{array}$ & $\begin{array}{l}.86529 \\
.65016 \\
.89563\end{array}$ & $\begin{array}{l}.967+ \\
.965+ \\
.966\end{array}$ & $\begin{array}{l}-2.8348+ \\
-2.1725+ \\
-2.0649\end{array}$ & $\begin{array}{l}2.0453 \\
1.4943 \\
2.9863\end{array}$ \\
\hline Reflective Observation & $\begin{array}{l}\text { Practice Criterion } \\
\text { Logical Thought } \\
\text { Active Particip ation }\end{array}$ & $\begin{array}{l}.39472 \\
.05559 \\
.85544\end{array}$ & $\begin{array}{l}.86529 \\
.77462 \\
.98968\end{array}$ & $\begin{array}{l}.9764 \\
1.000 \\
.862\end{array}$ & $\begin{array}{l}-2.0453 \\
-2.1288 \\
-1.9354\end{array}$ & $\begin{array}{l}2.8348 \\
2.2400 \\
3.6463\end{array}$ \\
\hline Logical Thought & $\begin{array}{l}\text { Practice Criterion } \\
\text { Reflective Observation } \\
\text { Active Participation }\end{array}$ & $\begin{array}{l}.33912 \\
-.05559 \\
.79984\end{array}$ & $\begin{array}{l}.65016 \\
.77462 \\
.8-837\end{array}$ & $\begin{array}{l}.965+ \\
1.0004 \\
.806\end{array}$ & $\begin{array}{l}-1.4943 \\
-2.24004 \\
-1.4797\end{array}$ & $\begin{array}{l}2.1725 \\
2.1288 \\
3.0794\end{array}$ \\
\hline Active Particip ation & $\begin{array}{l}\text { Practice Criterion } \\
\text { Reflective Observation } \\
\text { Logical Thought }\end{array}$ & $\begin{array}{l}-.46072 \\
-.85544 \\
-.79984\end{array}$ & $\begin{array}{l}.895634 \\
.98968 \\
.80837\end{array}$ & $\begin{array}{l}.9664 \\
.862 \\
.806\end{array}$ & $\begin{array}{l}-2.9863+ \\
-3.64634 \\
-3.0794\end{array}$ & $\begin{array}{l}2.0649 \\
1.9354 \\
1.4797\end{array}$ \\
\hline
\end{tabular}

In table 3.6 multiple comparisons, in sig. column the figure is respectively are 0.9760 .965 0.966 and etc which are all much higher than the accepted significant level .05. That again confirms the conclusion drawn from table 3.5.

All the data we obtain manifesting the one-way ANOVA is effective, and there is no significant difference among the four learning styles between learning style and students' perceived satisfaction with multimedia classroom environment. These results accord closely with the student satisfaction with on-line learning environment. The result of the ANOVA and multiple regression analysis is there was no significant relationship between student learning style and satisfaction with online environment. Further analysis using t-test on paired grouping of the learning styles showed that none of the LSI learning style was significantly related to perceived satisfaction with online situation.

The relationship between students' motivation and student satisfaction with multi-media classroom

Table3.7 Group Statistics

\begin{tabular}{|c|c|c|c|c|c|}
\hline Group & 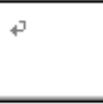 & $\mathrm{N}$ & Mean & \begin{tabular}{|l} 
Std. \\
Deviation
\end{tabular} & $\begin{array}{l}\text { Std. Error } \\
\text { Mean }\end{array}$ \\
\hline an24 & $\begin{array}{l}1.00 \\
2.00\end{array}$ & $\begin{array}{l}53 \\
48\end{array}$ & $\begin{array}{l}3.2264 \\
3.9792\end{array}$ & $\begin{array}{l}.84675 \\
7.12350\end{array}$ & $\begin{array}{l}.11631 \\
1.02819\end{array}$ \\
\hline
\end{tabular}

Table3.8 Independent Samples Test

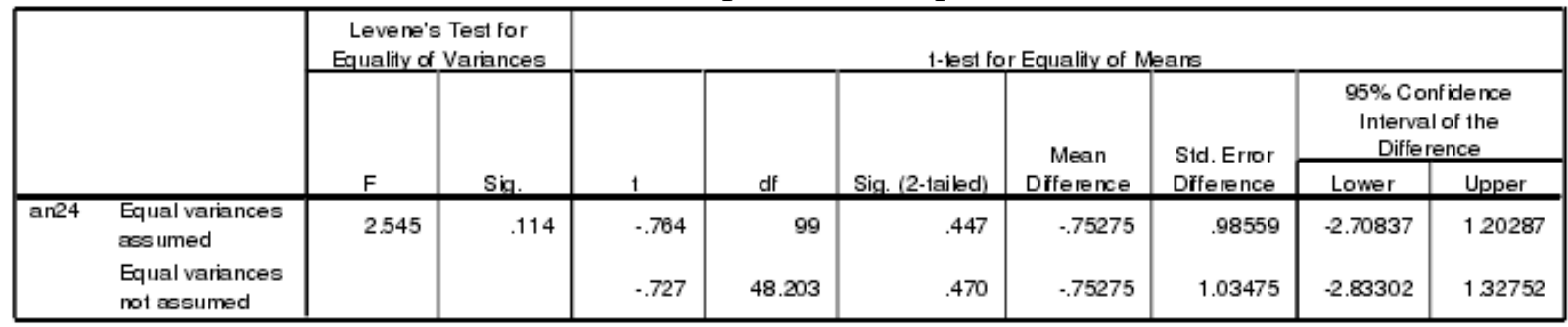

In table 3.8 the analysis shows sig. - .114 which is higher than .05.So there is no significant difference in perceived satisfaction between higher motivation group and lower motivation group. 3.2.3 The relationship between students' English level and student satisfaction with multimedia classroom

Table 3.9 Group statistics

\begin{tabular}{|l|l|l|l|l|}
\hline level & N & Mean & $\begin{array}{l}\text { Std. } \\
\text { Deviation }\end{array}$ & $\begin{array}{l}\text { Std. Error } \\
\text { Mean }\end{array}$ \\
\hline an24 11 & 100 & 3.0392 & $\begin{array}{l}1.43452 \\
4.99401\end{array}$ & $\begin{array}{l}.14204 \\
.50447\end{array}$ \\
\hline
\end{tabular}

In table3.9, we find out that the mean of the students' overall satisfaction with multimedia classroom in L3 is 3.6837 which is above the 3.5(generally accepted as high use and positive attitude), while the mean of the students in L1is 3.0392.which stands for medium degree of support. The L3 students have higher English proficiency than the students in L1, which means they can 
respond and react to the teachers' requirements more actively and energetically than L1 students. We teachers can easily find that the multimedia classroom environment in L3 is more active than in L1. To some extent the better interaction is between the students and teachers, the more harmonious relationship between the student and teachers. So adapted to the different English level, the teachers in L1 should adopt different approaches and methods from the L3 students to improve the L1 students satisfaction to a new level.

Table 3.10 Independent Samples Test

\begin{tabular}{|c|c|c|c|c|c|c|c|c|c|c|}
\hline & \multicolumn{2}{|c|}{$\begin{array}{c}\text { Levene's Test for } \\
\text { Equality of Variances }\end{array}$} & \multicolumn{7}{|c|}{ t-test for Equality of Means } \\
\hline & & \multirow[b]{2}{*}{$\mathrm{F}$} & \multirow[b]{2}{*}{ Sig. } & \multirow[b]{2}{*}{$\mathrm{t}$} & \multirow[b]{2}{*}{ dff } & \multirow[b]{2}{*}{ Sig. (2-tailed) } & \multirow{2}{*}{$\begin{array}{c}\text { Mean } \\
\text { Difference }\end{array}$} & \multirow{2}{*}{$\begin{array}{l}\text { Std. Error } \\
\text { Difference }\end{array}$} & \multicolumn{2}{|c|}{$\begin{array}{l}95 \% \text { Confide nce } \\
\text { Interval of the } \\
\text { Diffe re nce }\end{array}$} \\
\hline & & & & & & & & & Lower & Upper \\
\hline an24 & $\begin{array}{l}\text { Equal variances } \\
\text { assu med }\end{array}$ & 1.826 & .178 & -1.251 & 198 & .212 & -.64446 & .51523 & -1.66050 & .37159 \\
\hline & $\begin{array}{l}\text { Equal variances } \\
\text { not assu med }\end{array}$ & & & -1.230 & 112.311 & .221 & -.64446 & .52409 & -1.68284 & .39392 \\
\hline
\end{tabular}

In table 3.10 Independent Samples T- test the sig is .178 which is higher than the accepted significant level .05 .That means the test is efficient .And sig. (2-tailed) is respectively are .212 and .221. Both are higher than the significant level .05.It shows there is no significant difference in student satisfaction with the multimedia classroom environment. Then we can say the students with different English levels show different satisfaction with multimedia classroom environment, but not significant.

\section{Conclusion}

To improve the classroom learning, they must be satisfied with their learning experience. Therefore it is important to understand factors influencing their satisfaction level. [6]The purposes of this study were to explore the factors found salient in their perceived multi-media classroom learning. One -way ANOVA indicates that there is no significant different satisfaction with multi-media classroom among learning styles. Independent sample T-test indicates that there is no significant different perceived satisfaction between higher motivation group and lower motivation group, Independent sample T-test indicate was conducted again showing that there is no significant relationship between English competency and the overall satisfaction. Compared with the L1students medium level of satisfaction with the multimedia classroom, L3 students show more positive attitudes towards the classroom environment. This study provides insights for institutions to strengthen their multi-media classroom implementations and further improve learner satisfaction.

\section{Acknowledgement}

In this paper, the research was sponsored by Foundation of Hubei Educational Committee (Project No. 154017) and Education Development Foundation of Wuhan Textile University (Project No. 141141002).

\section{References}

[1] D Ignazio, Fred. The multi-media classroom: making it work [J]. Classroom Computer Learning, 1989(3):36-39.

[2] Leonard J.Waks. Computer mediated experience and education [J].Education Theory, 2001(5):415-432

[3]Jeffery A. Simmons. An investigation into the role of learning styles in student satisfaction with an on-line learning environment [D] 2006: 8-32.

[4] Yao-kuei Lee. Antecedents of learner satisfaction toward E-learning [J].Journal of American Academy of Business, Cambridge, 2007(11):161-169.

[5] [1] Gardner RC,MacIntyre PD.On the Measurement of Affective Variables in Second Language 
Learning. Language Learning Journal. 1993

[6] Horwitz, E.K. Language anxiety and achievement. Annual Review of Applied Linguistics. 2001(07):65-71 